\title{
Spatio-Temporal Dynamics of Climatological Variables in the Aid of Decision Making for Irrigated Agriculture
}

\author{
Roberto Filgueiras ${ }^{1}$, Matheus M. Reis ${ }^{2}$, Érika M. G. Lopes ${ }^{3}$, Rayssa B. Ribeiro ${ }^{1} \&$ Maria Camila A. Ramos ${ }^{1}$ \\ ${ }^{1}$ Department of Agricultural Engineering, Federal University of Viçosa, Viçosa, Brazil \\ ${ }^{2}$ School of Agricultural Engineering, Campinas State University, Campinas, Brazil \\ ${ }^{3}$ Institute of Agrarian Sciences, Federal University of Minas Gerais, Montes Claros, Brazil \\ Correspondence: Roberto Filgueiras, Agricultural Engineering Department, Federal University of Viçosa, Viçosa, \\ 36570-900, Brazil. Tel: 55-313-899-2732. E-mail: betofilgueiras@gmail.com
}

Received: February 13, 2019

Accepted: March 15, 2019 Online Published: May 15, 2019

doi:10.5539/jas.v11n6p292

URL: https://doi.org/10.5539/jas.v11n6p292

The research is financed by Coordenação de Aperfeiçoamento de Pessoal de Nivel Superior (CAPES, Brazil-Finance code 001) and Conselho Nacional de Desenvolvimento Científico e Tecnológico (CNPq, Brazil).

\begin{abstract}
The knowledge of the spatial-temporal dynamics of evapotranspiration is of great importance for the accomplishment of agroclimatic zoning and, therefore, for the design of irrigation systems and management of water use in irrigated perimeters. In this context, this study aimed to generate, with the aid of geotechnologies, information that can support irrigation systems planning and design, based on the temporal distribution of daily climatological normals and on evapotranspiration mapping for the irrigated perimeter of Gorutuba/MG. Climatic data were obtained from the meteorological station of the National Institute of Meteorology (INMET) of the municipality of Janaúba/MG in the period from 1985 to 2014. It was verified the non-tendentiousness and the temporal dependence of the climate data using variogram analysis and the temporal dependence index, respectively. For the interpolation, it was used ordinary kriging. The evapotranspiration mapping was conducted from 180 monthly images, from 2000 to 2014, of the MODIS sensor MOD16A product. The results generated for the irrigated perimeter provided relevant information for decision making of the irrigated agriculture management.
\end{abstract}

Keywords: irrigation, remote sensing, climatological normals

\section{Introduction}

The expansion of irrigated areas is often limited by the water availability, what makes it important to search for ways to increase the agricultural production by careful evaluations of the existing irrigated areas. This strategy enables to meet future demands of food and to soften the competition of different sectors for water, besides to reduce the irrigation impacts to the environment (Hamdy, Ragab, \& Scarascia-Mugnozza, 2003; Gheysari et al., 2017).

The science of irrigation systems assessment underwent a great development during the past 30 years, from a classic focus on irrigation efficiency (Bos \& Nugteren, 1974; Jensen, 1977) to performance indicators (Bos, Murray-Rust, Merrey, Johnson, \& Snellen, 1993; Clemmens \& Bos, 1990) and more recently to the quantification of the water use and productivity (Molden, 1998; Burt, 1997). The accounting framework of water and productivity developed by Molden (1998) can be used to evaluate the amount of water used and to determine the efficiency and the productivity of water use at several scales. The public domain data obtained by satellite and the scientific development makes the remote sensing an attractive option for irrigation systems management (Bastiaanssen \& Bos, 1999; Bos, Burton, \& Molden., 2004; Akbari, Toomanian, Droogers, Bastiaanssen, \& Gieske, 2007; Rozenstein, Haymann, Kaplan, \& Tanny, 2018). This spatial information is increasingly important for large irrigated areas, such as the Gorutuba irrigated perimeter.

The uses of evapotranspiration estimation algorithms are applied in digital images of any orbital sensor that performs radiance measurements in the visible, near-infrared and thermal, such as Terra/MODIS (Ruhoff et al., 
2012); Landsat 5-TM (Bezerra, Silva, Bezerra, Borges, \& Oliveira, 2012); Terra/ASTER (Santos, Fontana, \& Alves, 2010); and NOAA-AVHRR (Paiva, França, Liu, \& Filho, 2011).

The knowledge of a particular region's meteorological data is a key factor for the agricultural planning. In this context, the climatological normals are very important because they represent the reality in a more reliable way when compared to short time period data. One way to improve the understanding of these parameters is to represent them spatially and temporally (Sartori, Silva, Ramos, \& Zimback, 2010; Abatzoglou, Dobrowski, Parks, \& Hegewisch, 2018; Filgueiras, Oliveira, Cunha, \& Mantovani, 2018). It is possible, for this, to use geostatistical methodologies where such behavior is presented by means of thematic maps of the climatological parameters.

In this context, the study aimed to generate, with the aid of geotechnology, information that can support the planning and design of irrigation systems, based on the temporal distribution of daily climatological normals (air temperature, relative humidity, wind speed, insolation, precipitation and reference evapotranspiration) and on evapotranspiration mapping of the irrigated perimeter of Gorutuba, Minas Gerais northern region.

\section{Method}

\subsection{Study Area}

The study area is located in the Irrigated District of Gorutuba (DIG), in Nova Porteirinha county, located in the northern region of Minas Gerais state, between the pairs of coordinates $15^{\circ} 36^{\prime} 19^{\prime \prime} \mathrm{S} ; 43^{\circ} 19^{\prime} 49^{\prime \prime} \mathrm{W}$ and $15^{\circ} 50^{\prime} 23^{\prime \prime}$ S; 43 ${ }^{\circ} 14^{\prime} 06^{\prime \prime}$ W, Datum WGS-84 (Figure 1). The main crops in the region are banana, mango and mahogany, and banana crop corresponds to approximately $77 \%$ of the cultivated area (CODEVASF, 2016).

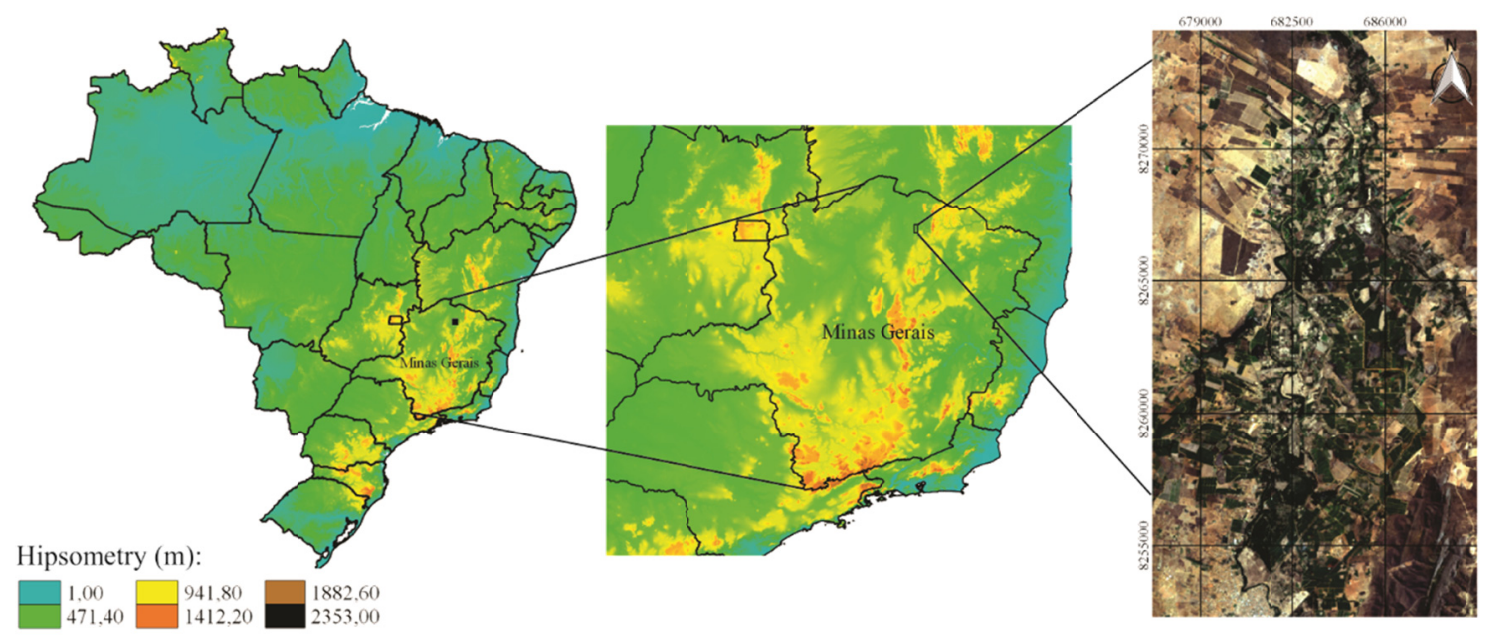

Figure 1. Location of the study area in relation to Brazil and Minas Gerais state.

The annual average rainfall in the region is about $817 \mathrm{~mm}$ and the annual average temperatures are between $22.9{ }^{\circ} \mathrm{C}$, in the coldest month, and $27.2^{\circ} \mathrm{C}$, in the warmest month. The region's climate matches the category Aw, according to the Köppen classification, in other words, warm tropical with dry winter (Alvares et al., 2013).

The daily rainfall (DR), maximum temperature (Tmax), minimum temperature (Tmin), insolation (Insol), air relative humidity $(\mathrm{RH})$ and wind speed $(\mathrm{U})$ data were obtained from conventional meteorological station (83395-Janaúba) of the National Institute of Meteorology (INMET), in the following geographical coordinates: $15^{\circ} 78^{\prime} \mathrm{S}$ and $43^{\circ} 30^{\prime} \mathrm{W}$, and $516 \mathrm{~m}$ altitude. To determine the daily reference evapotranspiration over the period under study, the methods of Penman Monteith (ETo-PM) (Allen, Pereira, Raes, \& Smith, 1998) and Hargreaves Samani (ETo-HS) (Hargreaves \& Samani, 1985) were used.

\subsection{Temporality of the Climatological Normal}

To define the climatological normals, daily data of a historical series over 30 years (1985-2014) were collected and calculated. Then, the average results for a one year period from these data were processed in the GS+9.0 software (Robertson, 2009). 
At first, the data exploratory analysis was performed by the descriptive statistics, by means of position measures and dispersion. Then, the geostatistical analysis was performed with the aim to quantify the time dependence degree between the random variables (Equation 1).

$$
\Upsilon(\mathrm{t})=\left(\frac{1}{2 \mathrm{~N}(\mathrm{t})}\right) \sum_{\mathrm{i}=1}^{\mathrm{N}(\mathrm{t})}\left[\mathrm{Z}\left(\mathrm{x}_{\mathrm{i}}\right)-\mathrm{Z}\left(\mathrm{x}_{\mathrm{i}}+\mathrm{t}\right)\right]^{2}
$$

where, $Y(t)$ is the semivariogram for a vector $\mathrm{t}$ in days; $\mathrm{Z}(\mathrm{x})$ and $\mathrm{Z}(\mathrm{x}+\mathrm{t})$ are the pairs of the variables analyzed in the study, separated by a time interval (days) and $\mathrm{N}(\mathrm{t})$ is the number of measured pairs.

After proving climate variables' time dependence and having the models' parameters adjusted, the interpolation was performed by the method of ordinary kriging, aiming to represent the temporal distribution of the studied climatological normals.

\subsection{Evapotranspiration Mapping}

The mapping of the reference evapotranspiration was performed using the information from the MODIS sensor. For this determination 15 years of MODIS products were used, totalizing 180 images. The reference evapotranspiration was estimated with the aim of being applied in irrigation systems design planning projects for the DIG. For this, the product MOD16 derived from TERRA platform (officially called EOS AM) belonging to NASA (Liu, 2015) was used. The data were acquired directly from an FTP portal provided by NTSG (Numerical Terradynamic Simulation Group).

The images were cropped and processed using the MRtools and QGIS 2.8.3 softwares. Some steps of the maps processing should be highlighted to obtain the reference evapotranspiration data in $\mathrm{mm} \mathrm{month}^{-1}$ : the images had to be converted to the Geotiff format, referenced and projected, and subsequently multiplied by 0.1 to convert the values to $\mathrm{mm}$ month $^{-1}$.

After performing the procedures above and obtained the monthly maps of reference evapotranspiration over the 15 years, it was necessary to apply to the images a logical operation. This was performed in the whole time series, with the aim of selecting the highest reference evapotranspiration values, pixel by pixel per month, as Equation 2.

$$
\mathrm{ETp}_{\mathrm{jan} \max }=\max \left(\mathrm{ETp}_{\mathrm{jan} 2000}, \mathrm{ETp}_{\mathrm{jan} 2001}, \ldots \mathrm{ETp}_{\mathrm{jan} 2015}\right)
$$

By these logics applied in all months of the year, the images of ETp $p_{\max }$ per month were generated, with the maximum values of each pixel of the DIG's area, during the 15 years of study.

\section{Results and Discussion}

The climate data of DR and U presented positive and the other variables presented negative skewness, which is confirmed by the average lower than the median. DR and Insol presented leptokurtic distribution, in other words, with kurtosis higher than zero, and the other climatic data presented platykurtic distribution, which indicates a tendency to have higher data dispersion close to the average. For descriptive analysis, the GS+ software (Robertson, 2009) adopts zero as pattern for mesokurtic distribution. According to the classification proposed by Warrick and Nielsen (1980), all the weather variables had a low variation coefficient (CV), except DR which was classified as high (Table 1). This high variation in DR data was also observed in other studies (Sartori, Silva, Ramos, \& Zimback, 2010; Gomes, Souza, Santos, \& Paiva, 2011) and can be explained by the lack of rainfall in dry months throughout the series.

Table 1. Descriptive statistics of the meteorological variables of rainfall (DR), maximum temperature (Tmax), minimum temperature (Tmin), insolation (Insol), air relative humidity (RH), wind speed (U), reference evapotranspiration by Hargreaves Samani (ETo-HS) and reference evapotranspiration by Penman Monteith (ETo-PM)

\begin{tabular}{lcccccccccc}
\hline Variable & $\mathrm{n}$ & Average & Median & $\mathrm{S}$ & $\mathrm{S}^{2}$ & $\mathrm{CV}(\%)$ & Min. & Max. & $\mathrm{Ca}$ & $\mathrm{Ck}$ \\
\hline $\mathrm{DR}$ & 365 & 2.24 & 1.04 & 2.72 & 7.41 & 121.41 & 0.00 & 12.16 & 1.33 & 1.15 \\
$\mathrm{~T}_{\max }$ & 365 & 31.58 & 31.75 & 1.28 & 1.64 & 4.05 & 28.64 & 34.20 & -0.19 & -0.81 \\
$\mathrm{~T}_{\min }$ & 365 & 19.27 & 20.04 & 1.84 & 3.39 & 10.47 & 15.27 & 23.54 & -0.40 & -0.92 \\
Insol & 365 & 7.98 & 8.31 & 1.12 & 1.27 & 7.12 & 3.78 & 9.77 & -0.90 & 0.28 \\
$\mathrm{RH}$ & 365 & 60.97 & 61.81 & 7.16 & 51.27 & 8.51 & 46.29 & 75.81 & -0.08 & -1.05 \\
$\mathrm{U}$ & 365 & 1.47 & 1.47 & 0.48 & 0.23 & 3.06 & 0.55 & 2.78 & 0.30 & -0.62 \\
ETo-PM & 365 & 4.47 & 4.51 & 0.49 & 0.24 & 9.12 & 3.22 & 5.70 & -0.14 & -0.65 \\
ETo-HS & 365 & 4.79 & 5.03 & 0.78 & 0.60 & 4.85 & 3.33 & 5.98 & -0.36 & -1.24 \\
\hline
\end{tabular}


The DR at DIG is more intense between the months of November and December, and in this period the occurrence of about $45 \%$ of the annual average of rainfall is observed. Between the second half of April and October, it is observed a period with very low rates of DR (Figure 2A). The higher Tmax values occur in the months of September and October, and the reddish color is noteworthy for that period in the Figure $2 \mathrm{~B}$. The higher values of Tmin occur with greater predominance in March (Figure 2C). This fact does not mean that high temperatures (Tmax and Tmin) will not occur at another time of the year, it only emphasizes the occurrence, more often, of high temperature values during these periods.

In a study on Köppen climate classification in Brazil, Alvares et al. (2013) also found that $45 \%$ of the annual average rainfall in Janaúba, MG (municipality where the DIG is located) occur in the months of November and December; and the months of June, July and August have the lowest average temperatures.
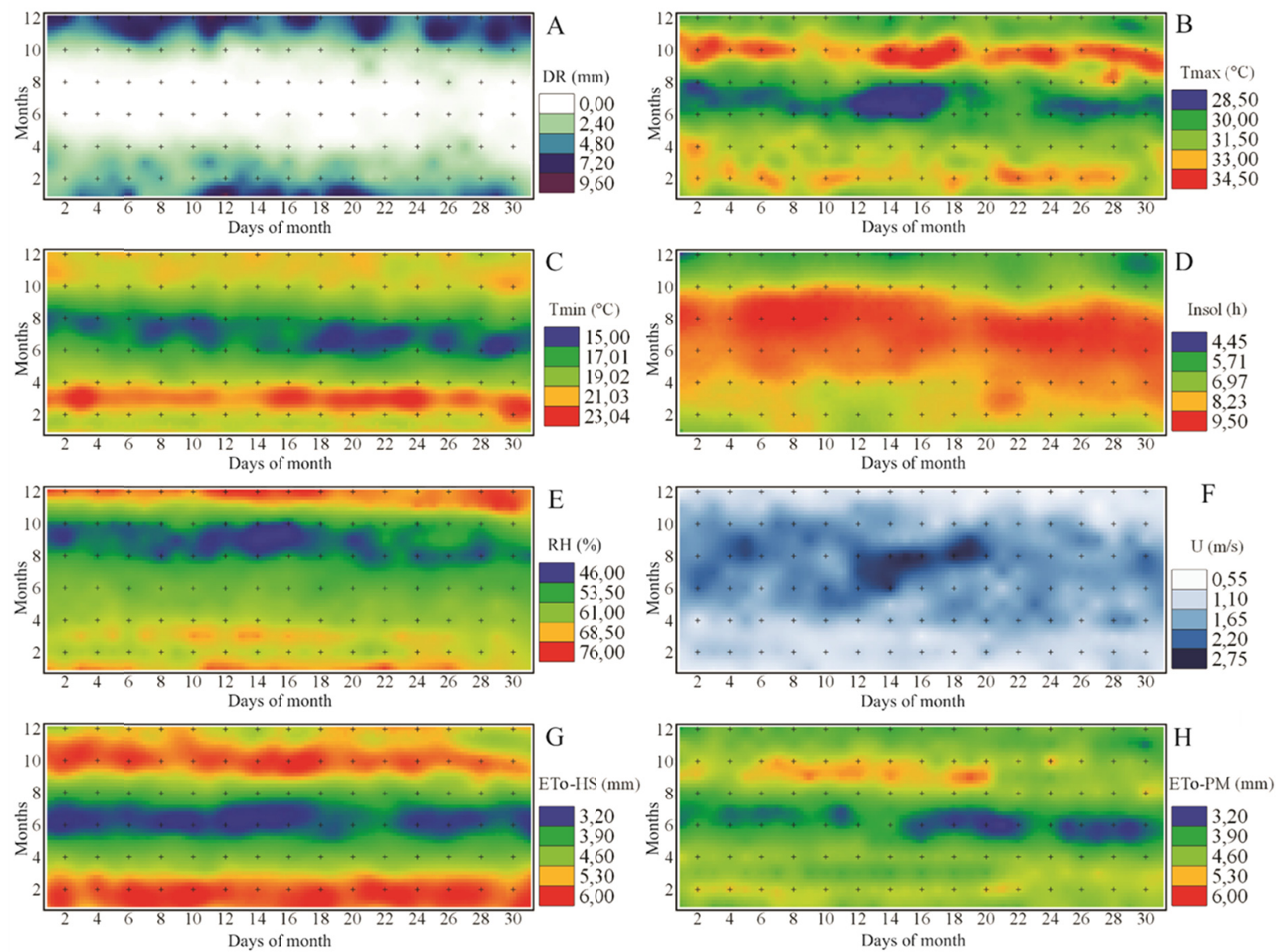

Figure 2. Average daily temporalization, during the year, of the meteorological rainfall (DR) (A), maximum temperature (Tmax) (B), minimum temperature (Tmin) (C), insolation (Insol) (D), air relative humidity (RH) (E), wind speed (U) (F), reference evapotranspiration by Hargreaves Samani (ETo-HS) (G) and reference evapotranspiration by Penman Monteith (ETo-PM) (H) data.

The largest Insol and U values occur between the months of June and October (Figures 2D and 2F). During this period, were also observed the lower RH values (Figure 2E). In relation to the values of the climatological normals of ETo-HS (Figure 2G) and ETo-PM (Figure 2H), both methodologies showed a similar behavior over time, however, the Hargreaves Samani methodology showed higher ETo values during the entire analysis. The Hargreaves Samani method was analyzed at the same time of the Penman Monteith method because it is a region characterized as semi-arid.

The climatological normals make possible to identify with greater reliability the periods in which the agricultural crops are most vulnerable to water, thermal and/or light stresses. In addition, they enable the agricultural activities planning on the properties inserted in the DIG, since there is greater certainty in the knowledge of climate variables dynamics during the year. 
The Figure 3 shows the maximum monthly potential evapotranspiration during the period from 2000 to 2014, for the DIG. The spatial distribution of these values was processed to serve as complementary information for the irrigation systems designer, since using these images, it becomes possible the knowledge of the maximum evapotranspiration occurred during 15 years for all the irrigated perimeter. This information can be used as a basis to estimate the project evapotranspiration, because the ETp estimation from the MOD16 product, according to $\mathrm{Mu}$, Heinsch, Zhao, and Running (2007), considers both the surface data, based on meteorological observations, and information from MODIS sensor observations.
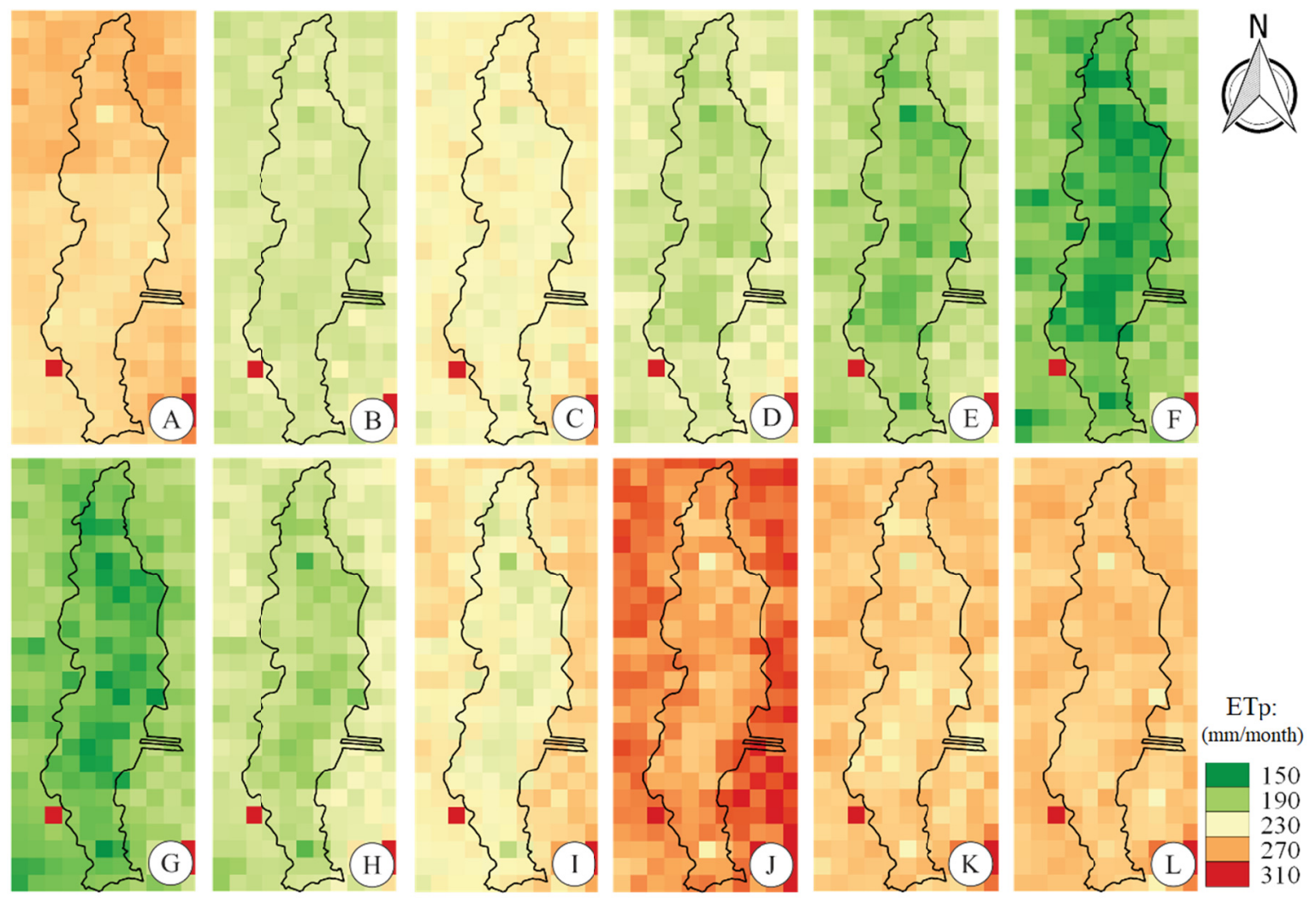

Irrigated Distrit of Gorutuba

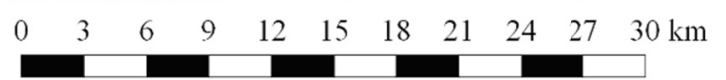

Figure 3. Maximum monthly potential evapotranspiration from 2000 to 2015 for the months: January (A); February (B); March (C); April (D); May (E); June (F); July (G); August (H); September (I); October (J); November (K) to December (L)

Westerhoff (2015) reports in his study that the MOD16 data, when compared to ETo data observed in the field, may be, possibly, used to estimate this parameter. The MOD16 calculation procedure considers the plant, which can be one of strength of this methodology to the implementation focused on irrigated agriculture. This same author highlights that the MOD16 product has potential for application in regional and in basin scales. Mu, Zhao, and Running (2011) report that the evapotranspiration estimated by the MOD16 exhibits a mean absolute bias of $24.6 \%$ when compared to meteorological towers data, emphasizing this result's acceptability, since the field data have an uncertainty that may range from 10 to $30 \%$.

\section{Conclusion}

(1) The temporalization of the climatological normals and the evapotranspiration monthly maps for the Gorutuba irrigated perimeter are promising tools for decision making in irrigation systems planning and design.

(2) These products enable the climate dynamics analysis over the year, identifying the periods with more favorable climatic conditions for agriculture, thus enabling better planning of agricultural activities at the DIG region. 


\section{References}

Abatzoglou, J. T., Dobrowski, S. Z., Parks, S. A., \& Hegewisch, K. C. (2018). TerraClimate, a high-resolution global dataset of monthly climate and climatic water balance from 1958-2015. Scientific Data, 5, 170191. https://doi.org/10.1038/sdata.2017.191

Akbari, M., Toomanian, N., Droogers, P., Bastiaanssen, W., \& Gieske, A. (2007). Monitoring irrigation performance in Esfahan, Iran, using NOAA satellite imagery. Agricultural Water Management, 88(1-3), 99-109. https://doi.org/10.1016/j.agwat.2006.10.019

Allen, R. G., Pereira, L. S., Raes, D., \& Smith, M. (1998). Crop evapotranspiration: Guidelines for computing crop water requirements. Rome: Food and Agriculture Organization of the United Nations. Retrieved from http://www.fao.org/docrep/X0490E/X0490E00.htm

Alvares, C. A., Stape, J. L., Sentelhas, P. C., de Moraes, G., Leonardo, J., \& Sparovek, G. (2013). Köppen’s climate classification map for Brazil. Meteorologische Zeitschrift, 22(6), 711-728. https://doi.org/10.1127/ 0941-2948/2013/0507

Bastiaanssen, W. G. M., \& Bos, M. G. (1999). Irrigation Performance Indicators Based on Remotely Sensed Data: A Review of Literature. Irrigation and Drainage Systems, 13(4), 291-311. https://doi.org/10.1023/ A:1006355315251

Bezerra, M. V. C., Silva, B. B. da, Bezerra, B. G., Borges, V. P., \& Oliveira, A. S. de. (2012). Evapotranspiração e coeficiente de cultura do algodoeiro irrigado a partir de imagens de sensores orbitais. Revista Ciência Agronômica, 43(1), 64-71. https://doi.org/10.1590/S1806-66902012000100008

Bos, M. G., Burton, M. A., \& Molden, D. J. (Orgs.). (2004). Irrigation and drainage performance assessment: Practical guidelines. Wallingford: CABI. https://doi.org/10.1079/9780851999678.0000

Bos, M. G., \& Nugteren, J. (1982). On irrigation efficiencies (3rd ed.). Wageningen: ILRI.

Bos, M. G., Murray-Rust, D. H., Merrey, D. J., Johnson, H. G., \& Snellen, W. B. (1993). Methodologies for assessing performance of irrigation and drainage management. Irrigation and Drainage Systems, 7(4), 231-261. https://doi.org/10.1007/BF00881553

Burt, C. M., Clemmens, A. J., Strelkoff, T. S., Solomon, K. H., Bliesner, R. D., Hardy, L. A., ... Eisenhauer, D. E. (1997). Irrigation Performance Measures: Efficiency and Uniformity.

Clemmens, A. J., \& Bos, M. G. (1990). Statistical methods for irrigation system water delivery performance evaluation. Irrigation and Drainage Systems, 4(4), 345-365. https://doi.org/10.1007/BF01103713

CODEVASF (Companhia de Desenvolvimento dos Vales do São Francisco). (2016). Distrito de Irrigação do Perímetro Irrigado Gorutuba. Retrieved from http://www.dig.org.br

Filgueiras, R., Oliveira, V. M. R. de, Cunha, F. F. da, \& Mantovani, E. C. (2018). Temporal dynamics of climatological parameters and hydric balance in the management of agricultural crops. Engenharia Agrícola, 38(5), 705-717. https://doi.org/10.1590/1809-4430-eng.agric.v38n5p705-717/2018

Gheysari, M., Sadeghi, S. H., Loescher, H. W., Amiri, S., Zareian, M. J., Majidi, M. M., ... Payero, J. O. (2017). Comparison of deficit irrigation management strategies on root, plant growth and biomass productivity of silage maize. Agricultural Water Management, 182(1), 126-138. https://doi.org/10.1016/j.agwat.2016. 12.014

Gomes, O. M., Souza, F. de A., Santos, C. A. C. dos, \& Paiva, W. de. (2011). Análise Geoestatística da Precipitação Pluvial do Estado da Paraíba. Análise Geoestatística da Precipitação Pluvial do Estado da Paraíba, 4(4), 692-702.

Hamdy, A., Ragab, R., \& Scarascia-Mugnozza, E. (2003). Coping with water scarcity: Water saving and increasing water productivity. Irrigation and Drainage, 52(1), 3-20. https://doi.org/10.1002/ird.73

Hargreaves, G. H., \& Samani, Z. A. (1985). Reference crop evapotranspiration from temperature. Applied Engineering in Agriculture, 1(2), 96-99. https://doi.org/10.13031/2013.26773

Jensen M. E. (1977). Water Conservation and Irrigation Systems: Climate Tech. Sem. Proc. Columbia, MO.

Liu, W. T. H. (2015). Aplicações de Sensoriamento Remoto (2nd ed.). São Paulo, SP: Oficina de Textos.

Molden, D. (1998). International Irrigation Management Institute, \& System-Wide Initiative for Water Management. Accounting for water use and productivity. 
Mu, Q., Heinsch, F. A., Zhao, M., \& Running, S. W. (2007). Development of a global evapotranspiration algorithm based on MODIS and global meteorology data. Remote sensing of Environment, 111(4), 519-536. https://doi.org/10.1016/j.rse.2007.04.015

Mu, Q., Zhao, M., \& Running, S. W. (2011). Improvements to a MODIS global terrestrial evapotranspiration algorithm. Remote Sensing of Environment, 115(8), 1781-1800. https://doi.org/10.1016/j.rse.2011.02.019

Paiva, C. M., França, G. B., Liu, W. T. H., \& Filho, O. C. R. (2011). A comparison of experimental energy balance components data and SEBAL model results in Dourados, Brazil. International Journal of Remote Sensing, 32(6), 1731-1745. https://doi.org/10.1080/01431161003623425

Robertson, G. P. (2009). GS+: Geoestatistics for the environmental sciences-GS+User's Guide (p. 152). Plainwell, Gamma Design Software.

Rozenstein, O., Haymann, N., Kaplan, G., \& Tanny, J. (2018). Estimating cotton water consumption using a time series of Sentinel-2 imagery. Agricultural Water Management, 207(30), 44-52. https://doi.org/10.1016/ j.agwat.2018.05.017

Ruhoff, A. L., Paz, A. R., Collischonn, W., Aragao, L. E. O. C., Rocha, H. R., \& Malhi, Y. S. (2012). A MODIS-Based Energy Balance to Estimate Evapotranspiration for Clear-Sky Days in Brazilian Tropical Savannas. Remote Sensing, 4(3), 703-725. https://doi.org/10.3390/rs4030703

Santos, T. V. dos, Fontana, D. C., \& Alves, R. C. M. (2010). Avaliação de fluxos de calor e evapotranspiração pelo modelo SEBAL com uso de dados do sensor ASTER. Pesquisa Agropecuária Brasileira, 45(5), 488-496. https://doi.org/10.1590/S0100-204X2010000500008

Sartori, A. A. C. da, Silva, A. F. da, Ramos, C. M. C., \& Zimback, C. R. L. (2010). Variabilidade temporal e mapeamento dos dados climáticos de Botucatu-SP. Irriga, 131-139. https://doi.org/10.15809/irriga. 2010v15n2p131

Warrick, A. W., \& Nielsen D. R. (1980) Spatial variability of soil physical properties in the field. In D. Hillel (Ed.), Applications of soil physics (p. 350). New York, Academic Press.

Westerhoff, R. S. (2015). Using uncertainty of Penman and Penman-Monteith methods in combined satellite and ground-based evapotranspiration estimates. Remote Sensing of Environment, 169, 102-112. https://doi.org/ 10.1016/j.rse.2015.07.021

\section{Copyrights}

Copyright for this article is retained by the author(s), with first publication rights granted to the journal.

This is an open-access article distributed under the terms and conditions of the Creative Commons Attribution license (http://creativecommons.org/licenses/by/4.0/). 